Din ve Bilim - Muş Alparslan Üniversitesi İslami İlimler Fakültesi Dergisi

Region and Science - Journal of Muş Alparslan University Faculty of Islamic Sciences e-ISSN: 2667-7717 Aralık/December 2020, 3(2): 83-96

\title{
Değişen Kent Ailesinde Sevgi Anlayışları ve İlişkilerine Sosyolojik Bir Yaklaşım
}

A Sociological Approach to Understandings and Relationships of Love in the Changing Urban Family

\section{Hatice GÜL}

Dr., PhD., Turkey

hgul11212@gmail.com

ORCID: 0000-0001-5905-3850

\section{Makale Bilgisi I Article Information}

Makale Türü / Article Type: Araştırma Makalesi / Research Article

Geliş Tarihi / Date Received: 07 Aralık / December 2020

Kabul Tarihi / Date Accepted: 14 Aralık / December 2020

Yayın Tarihi / Date Published: 31 Aralık / December 2020

Yayın Sezonu / Pub Date Season: Aralık / December

DOI: 10.47145/dinbil.837193

Bu makale, "Yeni Kentsel Ailenin Manevi Boyutları: Gaziantep Örneği" (Erciyes Üniversitesi, Sosyal

Bilimler Enstitüsü, 2019) başlıklı doktora tezinden üretilmiştir./ This article is extracted from my doctorate dissertation entitled "The Spiritual Dimensions of The New Urban Family: A Case Study in

Gaziantep", supervised by Professor Celaleddin Çelik (Ph.D. Dissertation, Erciyes University, Kayseri/Turkey, 2019).

Atıf / Citation: Gül, Hatice. “Değişen Kent Ailesinde Sevgi Anlayışları ve İlişkilerine Sosyolojik Bir Yaklaşım / A Sociological Approach to Understandings and Relationships of Love in the Changing Urban Family". Din ve Bilim - Muş Alparslan Üniversitesi İslami İlimler Fakültesi Dergisi 3/2 (Aralık 2020): 83-96. doi: 10.47145/dinbil.837193

İntihal: Bu makale, iThenticate yazılımınca taranmıştır. İntihal tespit edilmemiştir. Plagiarism: This article has been scanned by iThenticate. No plagiarism detected. web: https://dergipark.org.tr/tr/pub/dinbil I mailto: dinbil@alparslan.edu.tr

Copyright $\odot$ Published by Muş Alparslan Üniversitesi, İslami İlimler Fakültesi / Muş Alparslan University, Faculty of Islamic Sciences, Muş, 49250 Turkey. Bütün hakları saklıdır. / All right reserved. 


\title{
Öz
}

Aile tarih boyunca değişerek varlığını sürdüren bir kurumdur. Ailenin toplumsal hayattaki değeri ve önemi günümüzde giderek daha belirgin hale gelmektedir. Zira aile ve ailenin ilişkili olduğu her türlü yapı, toplumsal değişimlerin etkisinde kalmıştır. İçinden geçtiği değişim süreçleri; ailenin iç yapısında, roller ve ilişkiler sisteminde çok boyutlu farklılaşmalara yol açmıştır. Ailenin uğradığı en köklü ve sarsıcı değişimler, modernleşme ve kentleşme süreçlerinde meydana gelmiştir. Modernleşme ve kentleşme süreçleri; aile üzerindeki etkilerini en çok sosyalleşme, güvenlik, ekonomi ve sevgi gibi özel boyutlarda göstermiştir. Kentleşme sürecinin etkilediği aile yapısında sevgi faktörü; yuvanın kurulmasından, devamına ve aile içi ilişkilere kadar hemen her boyutta çok önemli bir faktör olarak karşımıza çıkmıştır. Bu bağlamda nitel yöntem ve tekniklerini kullandığımız doktora tez çalışmamızın verilerinden ürettiğimiz bu makale, değişim sürecindeki ailede eşler arasındaki sevgi ve bileşenlerinin konumlanışı ile işleyişini özel bir önemle ele almaktadır. Ayrıca bu çalışma; Gaziantep kent ailesi örneğinde sevginin değişimle birlikte ortaya çıkan yeni anlamlarını ve işlevlerini, sevginin eşler arasında düzenleyici ilişkisel önemini ortaya koymayı hedeflemektedir.

Anahtar Kelimeler: Din, Aile, Değişim, Sevgi, Fedakârlık

\begin{abstract}
Family is an institution that continues its existence by changing throughout history. The value and importance of family in social life is becoming increasingly apparent today. Because all kinds of structures that family and family are associated with have been affected by social changes. The change processes it went through have led to multidimensional differentiation in the family's internal structure, roles, and relationships system. The most radical and shocking changes experienced by the family have occurred in the processes of modernization and urbanization. Modernization and urbanization processes have shown their effects on the family most in special dimensions such as socialization, security, economy, and love. In the family structure affected by the urbanization process, the love factor has emerged as a very important factor in almost every dimension, from starting a family to maintaining the family, and domestic relations. In this context, this article, which we produced from the data of our doctoral thesis study in which we used qualitative method and techniques, deals with special importance the positioning and functioning of the components of love and love among spouses in the family in the process of change. In addition, this study aims to reveal the new meanings and functions of love that emerge with change, and the regulatory relational importance of love among spouses in the case of Gaziantep city family.
\end{abstract}

Keywords: Religion, Family, Change, Love, Sacrifice

\section{Giriş: Toplumsal Dönüşüm Sürecinde Aile}

Aile toplumdaki her kurum gibi belli bir toplumsal düzenin parçasıdır. Aileye dair yapılan tanımlamalar da ailenin toplumsal bir birim olduğu yönündedir. Buna göre aile, "ana-baba çocuklar ve tarafların kan akrabalarından (aile biçiminin gereğine göre) meydana gelmiş ekonomik ve toplumsal bir birliktir." ${ }^{1}$ Bir başka tanıma göre "biyolojik ilişkiler sonucu insan türünün devamını sağlayan, toplumsallaşma sürecinin ilk ortaya çıktığı, karşılıklı ilişkilerin belirli kurallara bağlandığı, o güne dek toplumda oluşturulmuş özdeksel ve tinsel zenginlikleri kuşaktan kuşağa aktaran, biyolojik, psikolojik, ekonomik, toplumsal, hukuksal vb. yönleri bulunan toplumsal bir birimdir."2 Bu ve benzeri tanımların özünde aile, aynı zamanda "sürekliliği olan ama değişimlerle kendini geleceğe taşıyan bir kurumdur."3

\footnotetext{
${ }^{1}$ Birsen Gökçe, “Aile ve Aile Tipleri Üzerine Bir İnceleme”, Hacettepe Sosyal ve Beşerî Birimler Dergisi 8/1-2 (Mart-Ekim 1976$), 48$.

2 Önal Sayın, Aile Sosyolojisi: Ailenin Toplumdaki Yeri (İzmir: Ege Üniversitesi Edebiyat Fakültesi Yayınları, 1990), 2.

${ }^{3}$ Kenan Çağan, “Ailenin İşlevleri," Aile Sosyolojisi, ed. Kadir Canatan - Ergün Yıldırım (İstanbul: Aç1ım Kitap, 2013$), 84$.
} 
Bugün ailenin içinde yaşadığı toplumsal dünyayı tanımlamak oldukça önemlidir. Günümüzde büyük çaplı değişimlerin niteliğini ve yönünü tayin edebilmek için risk toplumu, geç modernite, postgeleneksel toplum, düşünümsel modernite, akışkan modernite gibi kavramlardan yararlanılmaktadır. Söz konusu büyük çaplı söylemler esasen yaşanan değişimi ifade eden kavramlardır. ${ }^{4}$ Aile ile ilgili sosyolojik çalışmalar için önemli olan, yaşanan değişimin aile üzerindeki etkilerinin farklılaşarak devam etmesidir. Genel olarak bilinmektedir ki kavramlar olgulara dayandırılmakla birlikte insan zihninin ürünleridir ve üretildikleri bağlamlara göre değişirler. Dolayısıyla içinde bulunduğumuz dönem ister postmodern ister ileri/geç modern gibi kavramlarla tasvir edilmeye çalışılsın, bilimsel çalışmalarda önemli olan, önceden tayin edilmiş kavramların sınırlarına sıkışmak yerine yaşadığımız zamanın bize yansıyan sosyal eylem ve pratiklerini sosyal olgular üzerinden anlamaya çalışmak olmalıdır. ${ }^{5}$ Toplumsal düzenin bir parçası olarak aile, kentleşme ve modernleşme ile birlikte köklü değişmelere uğramıştır. Ailenin kentleşme ve modern süreçlerin etkilerine maruz kalması, ailenin maddi ve manevi yapısında birtakım değişimleri beraberinde getirmiştir. Modernleşmenin getirdiği iş bölümü ve cinsiyetler arası rol dağılımı, kadın ve erkeği aile olarak aynı mekânı paylaşabilecekleri uzun birlikteliklerden uzaklaştırmıştır. Kentleşmeyle birlikte ailede eşler arasında sevgi, saygı, sorumluluk, şefkat, güven, fedakârlık ve din vb. birçok manevi unsurlar arasındaki bağların, geleneksel aileye göre zayıflığı gündeme gelmiştir. Bilindiği üzere geleneksel ailelerde çevre ve akrabalık ilişkileri daha samimi ve güçlü dayanışma bağlarına sahipken kentleşme bu güçlü dayanışma bağlarını zayıflatmıştır. Kentsel toplumun karakteristiği heterojen bir yapı olmasından dolayı yabancılarla ve bilinmeyenlerle karşılaşma ve temas süreci, psikolojik şokların, sorunların ve sürprizlerin yaşandığı bir mecrayı oluşturmaktadır. ${ }^{6}$ Dolayısıyla tek bir yaşam tarzı ve tek tür aile yapısı kentlerin ayırıcı bir özelliği olmadığı için bu durumun, özellikle aile içi ilişkiler ve tutumlar ile yeni muhit ve mekânsal çevre dinamikleri arasında yaşanan süreçlere de etkide bulunduğunu belirtmeliyiz.

Esasen kentleşme, bireyin yaşam dünyasına öngörülemeyen birtakım sorunları da beraberinde getirmiştir. Kentleşme ve küreselleşmenin de etkisiyle teknolojinin günlük hayatı ve ilişkilerini dönüştürmediği aile yoktur. Günümüzün bireyi, yalnızlığını teknoloji marifetiyle telafi etmeye yönelmiştir. Kentli insanın teknolojiyle teması, aile içi yaşamı özgür kılarak eşlerin birbirlerine karşı sorumluluklarını geleneksel aileye göre esnetmektedir. Dışarıdan bakıldığında evliliğin getirdiği sorumluluklar, bu esneklik sebebiyle zayıflamış gibi görünmektedir. Hatta kentsel yaşamda bireyler arasındaki kişisel ve psikolojik bağların önemi, bu esneklik sebebiyle belirgin bir biçimde öne çıkmaktadır. Ancak diğer taraftan kentsel yaşamda geleneksel algı ve yaşayışı sürdüren ailelerin de var olduğunu görmek şaşırtıcı değildir. Nitekim günümüzün kentsel yaşamı farklı türden aile yapılanmalarını gündeme taşımaktadır. Dolayısıyla sadece modern aile biçiminin değil senkretik aile türlerinin de ortaya çıktığı bir süreci yaşamaktayız.

Kentleşme sürecinin yoğun etkileriyle karşı karşıya kalan ve modern/geç modern koşullarla kuşatılmış bir iklimden kaçınmada aile kurumu, üyelerine sağladığı güven ve huzur ortamıla öne çıkmaktadır. Ailenin ortaya çıkan bu belirgin yönü, kutsallıktan bir parçayı da taşıdığını göstermektedir. Bu manada aile, kutsallık yönüyle dinsel sınırların da ötesinde sonsuz manevi değerler alanı içinde kentsel yaşamın temel unsurlarından biri olmaya devam etmektedir. Aile içindeki önemi düşünüldüğünde kutsallık atfedilen diğer manevi değerler gibi sevgi olgusu da karakteristik yönleriyle öne çıkar. Sevginin; akrabalık, kardeşlik, romantik ilişki ve evlilik gibi olgu ve eylemleri tesis etmesi ve bu önemli yapıların zemini olması, sevginin aile yaşantısında çok yönlü

\footnotetext{
${ }^{4}$ Mustafa Günerigök, Risk Toplumu ve Din: Yeni Bir Sosyolojiye Doğru (Ankara: Maarif Mektepleri, 2018), 20.

${ }^{5}$ Hatice Gül, Yeni Kentsel Ailenin Manevi Boyutlarl: Gaziantep Örneği (Kayseri: Erciyes Üniversitesi, Sosyal Bilimler Enstitüsü, Doktora Tezi, 2019), 7.

${ }^{6}$ Kevin Robins, Into The Image: Culture and Politics in The Field of Vision (London: Routledge, 1996), 131.
} 
işlevlerinin olduğunu göstermektedir. Ailenin temelinde sevgi vardır. Sevgi duygu ve eylemi içerir. $\mathrm{Bu}$ bağlamda ailenin, sevginin eylem boyutuyla da bir anlam kazandığını belirtmek yanlış olmayacaktır. Bu makale, yeni kent ailesi ile ilgili doktora tez çalışmamızın sevgi başlıklı bölümünden elde ettiğimiz verilerden hareketle üretilmiştir. Nitel yöntem ve tekniklerini benimsediğimiz doktora tez çalışmamızın verilerinden ürettiğimiz bu makalede; sevginin aile içi ilişkilerde eşler için anlamı, eşlerin tutum ve davranışlarında birbirlerine sevgilerini gösterme biçimleri ve sevginin yakın akraba ilişkileri üzerinde yarattığı mücadeleci yönü ortaya koyulmuştur.

\section{Sevginin Anlamı: Manevi Gücün Ailevi Temeli}

Literatürde "sevme(k)" kelimesinin tanımıyla ilgili farklı yaklaşımlar olup bu yaklaşımların ikisinden geniş bir şekilde bahsedilmektedir. Yaygın bir şekilde kullanılan ise Bahr\&Bahr'ın geliştirdikleri yaklaşımdır. Birçok bilim adamı bu konuda onların geliştirdikleri tipolojiyi tercih etmektedir. Bahr\&Bahr'ın analizi çok yönlü ve güçlüdür. Onların sentezlerinde "aile sevgisi paradigması", sağlıklı birey ve aile için gereken "sevme(k)" duygusunu içeren üç önermeyi ele almaktadır. Birincisinde "sevme(k)", kabul/onaylanma ya da cömertlik; ikincisinde, kalıcllk; üçüncüsünde ise akraba ilişkilerine yönelik sorumlulukları içeren bir fedakârlık'tır. Ancak üçüncü önermedeki "fedakârlık"ta sevme(k), bir duygu olarak değil, bir eylem olarak ele alınmıştır. Burada önemli olan; ilişkilerde duygular, deneyimler ve hisler boyutundan çok "sevme eyleminin" ağır basmasıdır.7

Pitirim Sorokin; varlık bakımından sevginin "gerçek ve güzellikle yan yana, birleştirici, uyumlayan, yaratıcı enerji ya da gücün en yüksek biçimlerinden birisi" olduğunu belirtir. Sevginin birleştirici gücünü; karmaşıklığın, çekişmenin ve düşmanlığın karşısına koyarak uyum, birlik ve düzene vurgu yapar. Sevginin olmadığı yerde düşmanlık ve düzensizliğin hâkim olduğunu söyler. ${ }^{8}$ Sorokin'e göre "psikolojik yaşantı olarak sevgi, niteliği gereği 'özgeci'dir. Oysa karşıtı olan nefret, doğuştan bencildir. Gerçek sevgide sevilen insan her zaman amaç değildir; oysa bencil yaşantıda araç değer olmaktadır."9 Sorokin, sevginin kişisel yalnızlığı yok eden yönüne dikkat çekmektedir, intihar istatistikleri verilerine göre intiharın başlıca nedeninin yalnızlık olduğunu vurgular. Sevgi, bizim hayatımızı ve başka hayatları birbirine bağlayarak kendi hayatlarımızı insanlığımızın en soylu değerleriyle kıyaslanamayacak kadar zenginleştirmektedir. Sorokin, sevgi ile özgürlügü eşanlamlı olarak görür ve sevginin "en yüksek özgürlük biçimi” olduğunu ifade eder. Özgür olmayı, insanın sevdiği şeyleri yapması olarak kabul eder. Sorokin'e göre sevginin toplumsal görünümü de vardır: "Toplumsal alanda sevgi, bir insanın amaçlarının gerçekleşmesi sırasında, başkaları tarafından paylaşıldığı ve yardım gördügü, iki ya da daha çok insan arasındaki anlamlı ilişkidir." Seven bir insan, sevilen kişinin akla uygun amaçlarını gerçekleştirmesine yardım eder, onun mutluluğunu artırır. "Bu, vermek ve almak zevkidir; kendisini başkalarında ve başkalarıyla 'tatmin'dir. 'Dayanışma', 'karşılıklı yardım', 'iş birliği', 'iyi komşuluk', 'aile ilişkisi' ve bunlar gibi deyimler, toplumsal ilişki olarak sevginin çeşitli biçimlerini belirtmektedir." 10

Fromm, sevgi'yi "zorlama olmadan sadece özgür olunduğunda yaşanabilen, insan gücünü somutlayan bir eylem" olarak tanımlar. Kişinin kendi bütünlük ve bireyselliğini koruduğu, insanın "kendisi" olmasına yol açan duygu olduğunu ifade eder. Sevmek, bir eylemdir; edilgen bir duygu değildir. "Sevme"nin etken yapısının, almak değil öncelikle vermek olduğu söylenebilir. Ona göre sevgi, dayanışma yaşantısıdır; sevgi, üretici bir güçtür. Sevgi edimi esnasında bir şeyler üretilir ve bu

\footnotetext{
${ }^{7}$ Howard M. Bahr - Kathleen S. Bahr, Toward More Family-Centered Family Sciences: Love, Sacrifece and Transcendence (New York: Lexington Books, 2009), 116-117.

8 Pitirim Sorokin, "Özgeci Sevgi", çev. Mehmet Harmancı, Aşkın Anatomisi, der. A. Krich (İstanbul: Say Yayınları, 2005), $233-234$.

${ }_{9}$ Sorokin, "Özgeci Sevgi", 238.

${ }^{10}$ Sorokin, "Özgeci Sevgi", 239-241.
} 
üretime katılanlar yaşama bütün gücüyle bağlanır. Aksine güçsüzlük ise sevgi üretememektedir. Fromm, bu durumu Marks'in bir ifadesi ile dile getirir:

İnsanı insan olarak düşünün ve onun dünya ile ilişkileri de insanca olsun, o zaman sevgiyi sadece sevgiyle, güveni güvenle vs. değiştirebilirsiniz. Eğer sanattan tat almak istiyorsanız, sanatkârca eğitilmiş olmanız gerekir, eğer başka insanları etkilemek istiyorsanız, onlar üzerinde gerçekten uyarıcı ve geliştirici etki yapan bir kişi olmalısınız. İnsanlarla ve doğayla olan her ilişkiniz, sizin iradenizin nesnesi olan, gerçek bireysel yaşamınızın en net yansıması olmalıdır. Eğer sevginiz sevgi doğurmuyorsa bu, sevginizin, sevgi üretmediği anlamını taşır. Eğer seven kişi olarak yaşamınızı ortaya koyuyor ama sevilen bir kişi olamıyorsanız, sevginiz güçsüzdür. Şanssızlıktır. ${ }^{11}$

Fromm, böyle bir sevgiye "üretici sevgi" derken bununla sevginin toplumsal boyutuna dikkat çekmektedir. Fromm, üretici olduğu sürece sevginin güçlü olduğu vurgusunu yapmaktadır. Fromm'a göre sevginin verme unsurunun dışında, sevginin her türü için geçerli olan belli temel unsurları vardır. Bunlar ilgi, sorumluluk, saygı ve bilgi'dir. "Sevgi, sevdiğimiz şeyin büyümesi ve yaşaması için gösterdiğimiz etken ilgidir."12 Etken ilginin olmadığı yerde sevginin olamayacağını belirtir. Aksi takdirde çiçekleri sevdiğini söyleyip onları sulamayan kişinin sevgisine kim inanabilir. Sevginin bir unsuru olan ilgi ve bakım, sorumluluk duygusunu ortaya çıkarır. Sorumluluk tamamıyla iradi bir edim olup insanların gereksinimlerine verilen yanıttır. Saygı ise sevginin üçüncü unsurudur. Saygı ne korkmak ne de çekinmektir, "diğer kişinin olduğu gibi büyüyüp gelişmesine duyulan ilgi"dir ve sayg1, varlığını ancak özgürlügün temelleri üzerinden sürdürebilir. Fromm, sevginin diğer unsurunun ise bilgi olduğunu vurgular. Bir insanı tanımadan onu saymanın mümkün olamayacağına göre ilgi ve saygı, bilgi tarafından yönlendirilmektedir. Gösterilen ilgi, bilgiyi içermiyorsa anlamsızdır. "Gerçek bilgiye erişmenin tek yolu, sevme edimidir." Bu edim, sözlerin de düşüncenin de ötesine geçmektedir. Ona göre sevgi; ilgi duyma, sorumluluk, saygı ve bilme gibi davranış biçimlerini kapsar. İnsan sevdiği insanların gelişmesi ve mutluğu ile ilgilenir, edilgen olmaz. Sevdiklerinin ihtiyaçlarına karşlık verir, sorumluluk duyar. Aynı zamanda sevdiklerine sayg duyar ve onları tanır, bilir. ${ }^{13}$

Sevgi konusunda tanımlamalar ve çalı̧̧malar esasen çok fazla olmamakla birlikte birkaç bilim adamı da kuram geliştirmişlerdir. Örneğin, Sternberg ve Lee aşk kavramı üzerinde durarak belli sınıflandırmalar yapmışlardır. Sternberg sevgide; yakınlık, tutku, bağlılık gibi üç öğenin farklı bileşenlerinden oluşturduğu bir “üçgen aşk kuramı"nı geliştirerek sekiz aşk türünü ortaya koymuştur. Lee ise altı tip sevgi öğesini dairesel bir modelde öne çıkararak aşkı; eros (tutkulu), mania (bağımlı), ludus (oyun gibi aşk), pragma (mantıklı), storge (arkadaşça) ve agape (özgeci) aşk olarak sınıflandırmıştır. ${ }^{14}$

Kuşkusuz ki sevginin tanımı kişiden kişiye, kültürden kültüre ve yaşanılan çağa göre farklılık göstermektedir. Hatta aynı kültürde bile farklılaşan sevgi anlayışlarını görmek mümkündür. Özelikle kentleşmeyle birlikte değişen aile yapısında sevgi; aile içi ilişkilerin devamından tutun, ilişkinin başlangıcına ve eş tercihine kadar önemli bir faktör olarak karşımıza çıkmaktadır. Bu durumun geleneksel toplumlarda da bir karşılığı olmakla birlikte daha çok değişmekte olan kent aile yapısında öncelikli bir etken olarak öne çıktı̆̆ görülmektedir. Bütün bunlardan anlaşılan husus şudur ki sevgi duygusunun bireyler arasında aktarılmasıyla üretici ve paylaşımcı özelliğinin öne çıkması, onun ailesel ve toplumsal bir yönünün olduğunu gösterir. Bu da sevginin toplumsal yönü kadar kültürel yönlerini de ortaya çıkarır. Bu bağlamda düşünüldüğünde sevginin insanları birleştirici ve aile bağlarını güçlendirici bir rolü olduğunu görürüz.

\footnotetext{
${ }^{11}$ Erich Fromm, Sevme Sanatı, çev. Işıtan Gündüz (İstanbul: Say Yayınları, 1985), 30-33.

12 Fromm, Sevme Sanatı, 34.

${ }^{13}$ Fromm, Sevme Sanatı, 35-40.

${ }^{14}$ Hasan Atak - Nuray Taştan, "Romantik İliş̧kiler ve Aşk", Psikiyatride Güncel Yaklaşımlar 4/4 (Aralık 2012), 526-529.
} 


\section{Ailede Sevginin Dile Gelen Boyutları}

Birey ve toplum arasındaki ilk bağlantının mekânı olarak aile; üyeleri arasında sağlıklı sosyal ilişkilerin geliştirildiği, üyelerinin kolektif eylem potansiyelini açığa çıkarabildiği, normların ve kuralların içselleştirildiği ve sosyalleşmenin sağlandığı mekândır. Aile üyelerinin toplumla olan bağının varoluşsal bir gereklilik taşıması, bireyin kendini var edebilecek değer ve anlam duygularını içselleştirip dışarıya yansıtabilmesi, karşıdakini "sevme" duygusuyla başlar. Bu bağlamda sevginin ilk yeşerdiği mekân olarak ailede, üyelerin sevgi anlayışlarının kazanılmasında yaşanan süreçler, bireyin insanlarla sağlıklı ilişki kurmasında önemli derecede rol oynamaktadır.

Yeni kentsel ailenin manevi boyutlarını ele aldı̆̆ımız doktora çalışmamızda sevginin aile içindeki anlamına ilişkin özel bulgulara ulaştık. Sevginin anlamı üzerine elde ettiğimiz verilerde şu bulguları gözlemledik. Çalışmamızda kadın katılımcılar; sevgiye "fedakârlık, sadakat, değer ve saygı görmek, sorunlarının dinlenilmesi, paylaşılması ve anlaşılmak" gibi anlamlar yüklerken erkekler; daha çok "ilgi görmek, sıcak bir tebessüm, saygı duyulmak ve sorunları paylaşmak" gibi anlamlar tanımlamaktadır. Öte yandan erkekler için "nezaketli davranmak, eşe hâl ve hatır sormak" gibi ifadeler de bağlılığı ve yakınlığı güçlendiren sevgi anlayışı olarak ortaya çıkmaktadır. Sevgi anlayışlarının çok boyutlu olduğu, katılımcılarla yapılan görüşmelerde anlaşılmaktadır. Yapılan çalışmada sevgi kavramının hissi ve fiili şeklindeki ayrımının öne çıkması ise ilgi çekici bir bulgu olmuştur. ${ }^{15}$

Çalışmamızda "evlilikte sevginin eşler için anlamının" çok yönlü ve karmaşık bir doğası olduğu anlaşılmıştır. Sevgiyi anlama biçimlerinde kadın ve erkek cinsiyetinin pek de farklılaşmadığını söylemek gerekir. Ancak sevgiyi, eylemlerle gösterme biçimlerinde bir farklılığın olduğunu ifade edebiliriz. Esasen aileden gelen kültürel değerlerin, kadınların ve erkeklerin tutum ve davranışları üzerinde etkili olduğu anlaşılmaktadır. Mesela; bir erkek katılımcl, kendi ailesinin yanında eşine mesafeli davrandığını ifade ederken buna gerekçe olarak eşe yakınlık göstermenin kültürde hoş karşılanmadığını dile getirmiştir. Erkeğin kendi aile çevresinin olduğu yerlerde eşine daha mesafeli davranması, kadında bir kırgınlık yaratmakla birlikte kadının bu durumu çaresizce bir kabullenme eğilimine girdiği görülmektedir. Erkeğin kendi ailesinin yanında eşine mesafeli oluşunun temelinde esasen ilişki mahremiyetini başkalarının yanında alenileştirmekten çekinmesi yer alabilmektedir. Bazı erkek katılımcılar, ailelerinin yanlarında her ne kadar eşlerine sevgilerini gösterme noktasında rahat olamasalar da buna tezat olacak şekilde eşlerinden "saygı, ilgi ve hürmet" görmek istemektedirler. Kadınlar ise eşlerinden her durumda sevildiklerini hissetmeyi ve bunu, eşlerinin davranışlarında görmeyi beklemektedirler. Kadınlar, özellikle eşlerinin aileleri ile birlikteyken eşlerinin tutum ve davranışlarında sevgi görmeyi istemektedirler. Eşi tarafından sevildiğini hisseden kadın, erkeğin ailesine karşı kendisini daha güçlü hissetmektedir. Ancak aile içinde gerçekleşen sevgi edimlerinin başkalarının yanında sürmemesi veya daha sınırlı olması, kadınların çoğunlukla dile getirdiği hususlardan biri olmuştur. Sevginin başkalarının yanında eyleme dönüşmemesi veya eylemin sınırlı olması, kadınlarda eşlerine karşı sevgiyle ilişkili bir kırılma yaratsa da kendi özel mekânlarında sevgi duygusu eyleme dönüşmekte ve eşlerinin sevgisinden şüphe duymamaktadırlar. Zira erkekler kendi özel/mahrem mekânlarında sevgilerini daha rahat ifade etmektedirler. Netice itibariyle sevginin tutum ve davranışlarla gösterilme biçimlerinde daha çok içinde yaşanılan kültürün yansıması ortaya çıkmaktadır. 


\section{Aile İçi Yumuşak Rekabet Fırsatı: Sevgi Mücadelesi}

Evlilik yaşamı bir etkileşim ve iletişim sistemidir. Başarılı bir evlilikte karşılıklı sevgi, saygı, paylaşma ve uyum söz konusudur. ${ }^{16}$ Evlilikte bunların eksikliği, evlilik sürecini olumsuz etkilemektedir. Hatta ilgisizlik, sorumsuzluk, aldatma ve ekonomik sebepler asıl gerçek sebeplerin üstünü örtebilir. Eşler arasında sevgi, saygı gibi manevi değerlerin aşınması evlilik bağının zayıflamasına etkide bulunmaktadır. Fromm'a göre "Sevmek, yaratıcı bir etkinliktir. Bir insana (ya da şeye) ilgi duymayı, onu tanımak istemeyi, onu anlamayı, doğrulamayı ve onun yanındayken sevinç duyabilmeyi doğurur."17 Dolayısıyla sevmek, aynı zamanda üretici ve paylaşımcı özelliği ile öne çıkmaktadır. Bir başka deyişle sevginin üretilmesi ve paylaşılması, aile ilişkilerinde güçlü manevi bağlar yaratmaktadır. Aile üyelerinin sevgi ve ilgi duyguların birbirlerine iletmeleri, aile üyelerinin bireysel olarak değerli olduklarını ve aileye aidiyet duygusuyla bağlı olmalarını destekler ve geliştirir. ${ }^{18}$

Bilindiği üzere ailede sevgi öncelikli olarak eşler arasında başlar. Ancak evlilik zamanla olgunlaştıkça çoluk çocuk ve akrabalar devreye girmektedir. Dolayısıyla sevgi nesneleri çoğalır. Bir müddet sonra sevgi paylaşılmaya başlar. Bu aşamada evliliği etkileyen birçok unsur devreye girer. Aileye katılan bireyler sevgi paylaşım zincirinin içinde olmak ister. Aileye katılanların niceliği ve sevgi talepleri arttıkça ailede söz sahibi olma isteği artmaktadır. Dolayısıyla sevgi yoğunluğuna sahip olma isteği, neredeyse çatışma risklerini arttırarak iktidar mücadelelerine ve iktidar arzusuna dönüşmektedir. İktidar isteği, sevgi yoğunluğunu elinde bulunduranların amaçlarının gerçekleşmesine imkân sağlar. Bir başka deyişle kadın, eşinin yoğun ilgisiyle birlikte ailede güçlü duruma gelerek avantajlı bir duruma geçmektedir. Bu iktidar hissinin vermiş olduğu güvenle aile içerisinde, diğer aile bireylerine karşı edindiği üstünlük sayesinde hareketlerinde daha rahat davranır. Özellikle kayınvalide/görümce karşısında edindiği bu üstünlük sayesinde fazla bir çekince duymadan diğerlerine karşı iletişimini rahat sürdürmektedir.

Evliliğinin ilk yıllarında eşinin akrabaları yanında bir söz hakkı olmayan kadının zamanla aile içi konumunu sağlamlaştırma adına verdiği güç arayışları, aile içi savaşlara dönüşmektedir. Nitekim kentsel aile ortamı sadece kentin sorunlarından kaçmak için bir sığınak değil aynı zamanda kadınların diğerleriyle mücadele ve erkeğin ise idare alanıdır. Rus yazar Vladimir Solovyev'e göre bencilliğin olduğu bir yaşamda varlığın tüm hayatı, düşman çevreyle mücadele etmek ve kendini dünyaya karşı korumaktır. Yazara göre “... Bir varlık ötekine karşı düşmanca davranırsa, öbürleri de ona düşmanca davranmaktadır ...."19 Yaptığımız çalışmada bu durumun bir örneğini, eşi tarafından çok sevildiğini söyleyen ama eşinin ailesi yüzünden boşanmanın eşiğine gelen Tuğba'nın ifadesinde görebiliyoruz:

Eşimin ailesi eşimin beni sevdiğini bilir ancak eşimin bir özelliği ailesiyle birlikte olduğu zamanlarda, tüm ilgisini onlara yöneltir. Bana da yabancıymışım gibi davranır. Zaten kayınvalidemle çok yakın ve sıcak ilişki içerisinde değilim. Eşimin bana yabancı gibi davranması, eşimin ailesinin de bana o şekilde davranmasına yol açtı. Hatta biz eşimle yıllarca ailesi yüzünden tartışma ve kavgalar yaşadık. Eşimle boşanma aşamasına dahi geldik. Kayınvalidem rahmetli olduğunda onlarla iletişimimizi kopardık. Kocam tüm ilgisini bana ve çocuğuma yöneltti. $O$ taraftan sadece eşimin kardeşiyle görüşüyoruz. Biz neredeyse boşanıyorduk. Ama mücadeleden vazgeçmedim (Tuğba B., Ev Hanımı, 37).

Başka bir örnekte ise Pelin'in anlattığına göre eşi, Pelin'e olan sevgisini her yerde göstermektedir. Öyle ki Pelin, eşinin akrabaları yanında eşinden sevgi ve ilgi görmenin avantajlarını yaşamaktadır:

\footnotetext{
16 İbrahim Ethem Özgüven, Evlilik ve Aile Terapisi (Ankara: PDRM Yayınları, 2000), 73.

${ }^{17}$ Erich Fromm, Sahip Olmak ya da Olmak, çev. Aydın Arıtan (İstanbul: Arıtan Yayınevi, 2003), 73.

18 Özgüven, Evlilik ve Aile Terapisi, 71.

${ }^{19}$ Sorokin, "Özgeci Sevgi", 235.
} 
Her karı koca gibi bizim de sorunlarımız oluyor. Kocam empati sahibi birisidir, beni başkalarının yanında zor durumda bırakmak istemez. Bu yüzden kendi ailesinin yanında sürekli benim yanımda olduğunu davranış ve tutumlarıyla gösterir, kayınvalidem ve kayınlarımdan gelebilecek herhangi bir laf sokma karşısında korumacı davranır, cevabını verir. O yüzden kimse bana bir şey diyemez, kocam beni sevdiğini saydığını gösterince, onlar da bana karışmazlar, saygı duyarlar (Pelin A., Yönetici Asistanı, 41).

Kimi zaman gelin ve kayınvalide arasındaki iktidar savaşları arasında kalarak kendini ifade etmede zorlanan erkekler, kadınların sevgi talepleri arasında gelgitli bir tavır sergilemektedir. Kadın açısından sevginin gerektiği yerde eyleme dönüşmemesi durumu, kadınlarda eşlerine karşı bir kırılma yaratmaktadır. Tam da en zorlandıkları noktada ilgiyi ve sahiplenilmeyi hissedemeyen kadın, bu kırılmayı daha fazla yaşamaktadır. Ancak burada olumlu kabul edilebilecek bir durum ise Türk ailesinde, erkek ailesinin ve kadının bu güç savaşlarında çok ileri gitmeme gibi bir eğilim içinde olmalarıdır. Zira her iki rakip taraf da ortak sahip oldukları kişinin sevgisini kaybetmemek ve yaşanabilecek daha büyük tartışmaların önüne geçebilmek adına kendiliğinden bir anlaşma sistemi yani "1lımlı bir diyalog" geliştirmişlerdir. Bu yol ile rakip tarafların çok ileri gitmediği, birbirlerine laf atmalar ve imaların geçici bir süre ertelendiği, çay/kahve vs. gibi ikramlarla münakaşaların üstünün örtüldüğü görülmektedir. Nitekim her iki rakip taraf da gerilimin yükselmemesi için susmayı tercih eder. Esasen rakip taraflar arasında yaşanılan olayların yoğunluğu çok yüksek değilse bir anlaşma sistemi kendiliğinden mevcuttur. Anlaşılan o ki sevgiyi paylaşma kadar paylaşamama duygusu da kaçınılmaz olarak sevginin doğasında içkin gözükmektedir. Rakip taraflar arasında ortaya çıkan olası gerilimlerde kadınların eşlerinden talep ettikleri sevginin, başkalarının yanında eyleme dönüşmemesine rağmen bu duruma kadınların alıştıkları sonucuna varıyoruz. Nitekim erkeklerin, eşlerine karşı hissettikleri sevginin duygu boyutunda bir kırılma yaşanmamaktadır. Ancak sevginin eyleme dönüşmemesi durumu, erkeklerin kendilerini dışarı yansıtma eğilimlerinin farklı bir dokuya sahip olduğunu göstermektedir. Dolayısıyla erkeğin ve kadının sevgi davranışlarının farklılığında, aileden gelen kültürel değerlerinin etkisinin olduğunu söyleyebiliriz. ${ }^{20}$

\section{Sevginin Ailedeki Görünümleri: Bir Hâl Olarak Sevgi}

Ailede sevgi söz konusu olduğu zaman sevgiyle ilişkili birçok unsur da önem kazanmaktadır. Katılımcıların sevgi anlayışları ile ilgili ifadelerindeki bazı kilit özelliklere bağlı olarak, ailede sevgiyi anlama ve eyleme dönüştürmede saygl, fedakârlık, sorumluluk, güven, nezaket, şefkat ve din gibi manevi bileşenlerin öne çıktığını görüyoruz. Sevgi ve öne çıkan bu manevi bileşenler arasında güçlü bir etkileşim olmakla birlikte evliliğin sürdürülmesinde de önemli rolleri bulunmaktadır. Satir için sağlıklı aile; eşler arasında sevgi ve saygının karşılıklı olduğu, üyelerinin birbirlerine değer verip saygı gösterdiği bir ailedir. ${ }^{21}$ Daha öncede belirttiğimiz üzere Fromm saygıyı, sevginin bir bileşeni olarak görmektedir. Aile içi ilişkilerde sevgi ve saygı kavramları neredeyse iç içe geçmiştir. Hatta saygının olmadığı bir ailede sevgiden bahsetmek neredeyse imkânsızlaşır. Boşanmanın birçok nedeni arasında bile saygısızca tutum ve davranışlar önemli bir faktör olarak karşımıza çımaktadır. Kuşkusuz ki bu kadar iç içe geçmiş iki önemli manevi unsurdan birinin eksikliği, evlilik ilişkilerinin aleyhine sonuçlanacak bir durumu kaçınılmaz kılmaktadır.

Sevgi ile ilgili üzerinde durulması gereken ve literatürde genellikle göz ardı edilen en önemli manevi bileşenlerden biri "fedakârlık"tır. Fedakârlık, bir kişinin, partnerinin ya da ilişkisinin iyiliği için kendi çıkarlarından vazgeçmesi olarak tanımlanmaktadır. ${ }^{22}$ Van Lange, Rusbult ve arkadaşlarının yaptığı çalışma, fedakârlığın evlilik gibi yakın ilişkiler üzerindeki etkilerini araştırma açısından ilk

\footnotetext{
${ }^{20}$ Gül, Yeni Kentsel Aile, 121-122.

${ }^{21}$ Virginia Satir, İnsan Yaratmak: Aile Terapisinin Başyapıtı, çev. Selim Yeniçeri (İstanbul: Beyaz Yayınları, 2018), $27-32$.

22 Paul A. M. Van Lange vd., "Willingness to sacrifice in close relationship", Journal of Personality and Social Psychology 72/6 (1997), 1374.
} 
çalışmadır denilebilir. Onlar, fedakârlık/özveri ile ilgili birtakım incelemelerden sonra bir dizi çalışma gerçekleştirmişlerdir. İlişkilerin işleyişiyle ilgili fedakârlık olgusuna dair yaklaşımlarında dört temel ilke belirlemişlerdir. Bunlar; fedakârlığın karşılıklı olduğu, fedakârlığın aile üyelerinin problemlerini çözmeye yönelik olduğu, ilişkilerde iş birliği ve güven ortamı yaratması ve fedakârlığın bir iletişim işlevi görmesidir. ${ }^{23}$

Bilimsel literatürde fedakârlık konulu çalışmaların çok az olması, bizi bu konuyla ilgili verileri sunarken kısıtlı bir duruma sokmaktadır. Çalışmamızda katılımcılara sevgi anlayışlarıyla ilgili sorular yönelttiğimizde özellikle kadınlar tarafından "fedakârlık" kelimesinin öne çıktığını gözlemledik. Fedakârlığın anlamı; erkek katılımcıların ifadelerinde "evliliğin sürdürülmesi, eş ve çocuklar için her şeyi yapmak, beklenti ve isteklerden vazgeçmek" gibi anlamlara gelmekteyken görüşülen kadınların fedakârlığın anlamına ilişkin ifadelerinde ise genellikle "aileyi her türlü tehlikelere karşı korumak, mücadele etmek, eşle inatlaşmamak/eşi idare etmek, eşin kötü huylarını görmeyip iyi huylarını öne çıkarmak, ev işleri ve düzenini sürdürmek" gibi çeşitli anlamların öne çıtığı görülmüştür. Çalışmamızda fedakârlığın çeşitleri ve dereceleri aynı olmasa da fedakârlığın anlamı konusunda katılımcıların algılarında ortaya çıan benzerlikler dikkat çekicidir. Dolayısıyla katılımcılarla yaptığımız görüşmelerde evliliğin devamı için fedakârlığın eylemsel yönünün anlamlı bir biçimde öne çıktığı ve aile içi ilişkileri güçlendirdiği görülmüştür. Ayrıca fedakârlığın eylemsel boyutunun aile düzenine yaptığı katkının eşler arasında ilişki memnuniyetini arttırdığı da anlaşılmıştır.

Sevgi ve aile kavramları birlikte ele alındığında bu iki kavram arasında yakın bağı sağlayan kuşkusuz ki "fedakârlık" olmaktadır. Çünkü eşlerin fedakârlık kavramına yüklediği anlam, bizi sevgi kavramına götürmektedir. Bu yüzden sevgi ve fedakârlık kavramları birbirinden ayrı tutulamaz. Ancak bazı istisnai durumlar da ortaya çıkabilmektedir. Mesela; bazı kadın katılımcılar evliliği sürdürme gerekçesi olarak "yuvam için, çocuğum için" cevabını verirken sosyoekonomik özgürlüğü olan kadınlar "kendim için" cevabını vermiştir. Esasen "kendim için” cevabının altında daha özgürce ve bağımsız bir sevginin yattığını söyleyebiliriz. "Yuvam için, çocuğum için" cevabı daha kapsayıcı ve daha özverili bir sevgi anlayışını ortaya koymaktadır. Burada sevgi ve fedakârlık arasında yakın bağlar olsa da aralarında karışık bir dokunun da varlığını görmekteyiz. Bu durum sevgi içeriği kadar fedakârlık içeriğinin de geniş ve derin bir boyuta sahip olduğunu gösterir. ${ }^{24}$

Şefkat genellikle sıcaklık, incelik, nezaket gibi özelliklerle karıştırılarak kullanılan bir kavramdır. Bu özellikler, bir insanda önemli olmasına rağmen şefkat bunları da aşan bir anlama sahiptir. ${ }^{25}$ Hökelekli şefkat kavramını; kişinin çevresindeki insanları koruma, himaye altında bulundurma, onları kabullenme, yakından ilgilenme, onlara sevecenlik ve sempati ile yönelme davranışında bulunma olarak açıklar. ${ }^{26}$ Popüler kullanımda şefkat daha çok bir annenin çocuğuna olan duygusu anlamında kullanılsa da şefkat ve acıma duygusu birbirine karıştırılabilmektedir. Şefkat, acıma ile aynı manaya gelmemektedir; bir kişiye şefkat göstermek, şefkat gösterilen kişinin zayıf olduğu anlamına gelmemektedir. ${ }^{27}$ Çalışmamızda kadın katılımcılara göre şefkat, karşı cinsten "yoğun ve sürekli bir karşılık görme beklentisini" içermektedir. Başka bir ifadeyle kadınlar, duygularının paylaşılması ve dertlerinin dinlenilmesini istemektedirler. Erkek katılımcılara göre ise şefkatin anlamı, kadınların şefkat anlayışlarından biraz daha farklılaşmaktadır. Onlar; şefkat

\footnotetext{
${ }^{23}$ Van Lange vd., "Willingness to sacrifice in close relationship", 1376; Wesley R. Burr vd., Sacred Matters: Religion and Spirituality in Families (New York: Routledge, 2012), 71-73.

${ }^{24}$ Gül, Yeni Kentsel Aile, 122-126.

${ }^{25}$ Alys Cole-King - Paul Gilbert, "Compassionate Care: The Theory And The Reality”, Journal Of Holistic Healthcare 8/ 3 (2011), 30.

${ }^{26}$ Hayati Hökelekli, “Şefkat” Dem Dergi 3 (Ocak-Şubat-Mart 2008), 109.

${ }^{27}$ Cole-King - Gilbert, "Compassionate Care: The Theory And The Reality", 30.
} 
duygusunu karşı cinsten "nezaketle davranılmak, ilgilenilmek, anlayış ve sabır" anlamında ele almışlardır. ${ }^{28}$

Nezaket de şefkat gibi sevginin önemli tezahürlerinden biridir. Nezaket, diğerlerine karşı kırıcı üslup ve davranışların önüne geçerek aile üyelerine karşı gösterilen şefkati ve önemi gösterir. Evlilik her şeyden önce bir iletişim ve etkileşim ağıdır. ${ }^{29}$ Başarısız bir ilişkinin temelinde başarısız bir iletişim vardır. ${ }^{30}$ Eşler arasında sağlıklı bir iletişimin olmayışı, eşler arasında sorunların algılanıp kavranmamasından kaynaklanmaktadır. Evlilikteki iletişim trafiğinde eşlerin duygu ve düşüncelerini birbirlerine iletiş tarzındaki eksiklikler, yanlış ifadeler çok basit görünen olayları ve konuları üst derecede sorunlar yumağına dönüştürebilmekte ve eşler arasında çatışmalar kaçınılmaz olmaktadır. ${ }^{31}$ Kaba tutum ve davranışlar, aile içi iletişimin sağlıklı yürütülmesinde gerekli temel birtakım unsurları göz ardı eden olgular haline gelebilmektedir. Evlilik üzerine çalışmalar yapan Gottman'a göre bir evliliğin bitip bitmeyeceğinin en iyi belirtilerini, eşlerin tartışma biçimlerinde görmek mümkündür. ${ }^{32}$ Yeni kentsel aileyi mercek altına aldığımız niteliksel çalışmamızda görüşme yaptığımız katılımcılar için nezaket ve görgü kurallarına dikkat etmek; eşler arasındaki iyi iletişimi pekiştiren, saygıyı ve dostluğu arttıran hususiyetler olarak ifade edilmiştir. ${ }^{33}$ Nitekim eşler arasında nezaketli dil, duyguları dostluğa dönüştürmekte ve saygıyı arttırmaktadır. Mutlu evliliğin temelinde eşler arasında derin bir dostluk bağı yatmaktadır. ${ }^{34}$ Dostluk bağına giden yol ise nezaketli iletişimden geçmektedir. Eşler, özellikle tartışma sırasında incelikli bir yaklaşım sergileyemiyor ve eleştiri ve hakaret içerikli bir tutumla hareket ediyorsa bu durum tartışmaların daha da yükselmesine sebep olmaktadır. Özellikle yüksek sesler, kötü sözler ve ilgisizlik eşleri birbirinden soğutmakla birlikte eşe hitap biçimi, şefkat göstermeme, kaba konuşmalar ilişkilerde yaşanabilecek birçok problemi ve çatışmayı tetiklemektedir. Nezaket içeren davranışlar ise aile içinde çıkabilecek münakaşa, misilleme gibi olumsuz durumları azaltarak aile ilişkilerini güçlendirmektedir. ${ }^{35}$ Evlilikte eşlerin duygu ve düşüncelerini birbirlerine aktarma biçimlerinde yaşadıkları sorunlar aile içi çatışmaların ve geçimsizliklerin önemli nedenini oluşturmaktadır. Dolayısıyla görüşme yaptı̆̆ımız erkek ve kadın katılımcıların da bu konuya oldukça duyarlı yaklaştıkları görülmüştür.

Sorumluluk duygusunu sevginin bir bileşeni kabul eden Fromm, sorumluluğun dışarıdan kişiye atfedilmiş bir görevden ziyade tamamıla iradi bir davranış olduğunu ifade eder. Ona göre sorumluluk, diğer insanların gereksinmelerinin karşılanmasıdır. ${ }^{36}$ Bir başka deyişle sorumluluk hissini birey, kendi yaratmalıdır; bunu dışarıdan dayatılan bir görev gibi algılamak bireyi iradesi dışında davranmaya sürükler. Söz konusu aile olduğu zaman eşlerin birbirleriyle ve çocuklarıyla olan ilişkilerinde birbirlerinin gereksinimlerine karşı duyarlı davranması neredeyse aile kurumu için bir gereklilik haline gelmiştir. Aile olmanın bilincinde olan bireyler, evlilikte ortak sorumluluklarının farkında olarak hareket ederler. Bu yüzden evliliğin yürütülmesinde eşlere büyük roller düşmektedir. Özellikle kadınlara evliliğin yürütülmesinde düşen görev ve sorumluluklar kadını daha fazla fedakârlığa iterek aile kurumunu kutsal bir kategoriye yerleştirmektedir. Çalışmamızda görüşme yaptığımız katılımcılar; evlilik ilişkilerinde rollerin, sorumlulukların ve aile içi özgürlük sınırlarının önemine ve muhafazasına dikkat çekmişlerdir. Özellikle de bir evlilikte "biz" duygusunun eşler tarafından idrak edilebilmesinin önemine vurgu yapmışlardır. Kuşkusuz ki bir evlilikte sorumluluk

\footnotetext{
${ }^{28}$ Gül, Yeni Kentsel Aile, 139-142.

29 Özgüven, Evlilik ve Aile Terapisi, 73.

${ }^{30}$ Zygmunt Bauman, Akışkan Aşk, çev. Işık Ergüden (İstanbul: Versus Kitap, 2012), 34.

31 Özgüven, Evlilik ve Aile Terapisi, 73, 83, 84.

32 John Gottman - Nan Silver, Evliliği Sürdürmenin Yedi İlkesi, çev. Ezgi Deniz (İstanbul: Varlık Yayınları, 2013), 32.

${ }_{33}$ Gül, Yeni Kentsel Aile, 133.

${ }^{34}$ Gottman - Silver, Evliliği Sürdürmenin Yedi İlkesi, 25.

${ }^{35}$ Burr vd., Sacred Matters, 102-103.

${ }^{36}$ Fromm, Sevme Sanatt, 35.
} 
kadar göz ardı edilmemesi gereken bir husus da özgürlüğün sınırlarının çizilmesidir. Evlilik öncesi bireysel özgürlüklerini evliliğin inşasından sonra da devam ettiren eşler, ilişkilerinde birtakım sıkıntılarla karşılaşmaktadırlar. Özellikle evlilik gibi düzen ihtiyacının önemli olduğu bir kurumda özgürlük ve sorumluluk alanlarında bir dengesizlik, aile içi ilişkileri olumsuz etkilemektedir. Ailenin düzene olan ihtiyacı, sorumluluk ve özgürlük alanlarında ancak bir denge ve istikrarla karşılanabilir. Bu da eşlerin tutum ve davranışlarında birbirlerinin özgürlüklerine müdahalelerini sınırlı tutmalarını, farklılıklarını kabul etmelerini ve sorumluluklarını bilmelerini gerektirir. ${ }^{37}$

Sevgiyle yakından ilgili bir diğer unsur da "güven" duygusudur. Zira güven ikili ilişkilerimizi ve diğer insanlarla olan ilişkilerimizi sağlıklı bir şekilde sürdürmemiz için en temel gereksinimlerimizden biridir. Güven duyamadığımız insanlardan uzaklaşır ve iletişimimizde itinalı olmaya gayret ederiz. Güven; bireylerin aile üyeleri, arkadaşları ve iş arkadaşlarıyla devam eden ilişkilerinin en önemli özelliklerinden biridir. ${ }^{38}$ Güvenin birçok olumlu etkileri vardır. Örneğin romantik ilişkilerde ve dostluklarda güven; samimiyet, bağışlama ve fedakârlık istemede kilit bir rol oynar. ${ }^{39}$ İş arkadaşlarımızla olan ilişkilerde bile güven; takım çalışmasını, sosyal etkileşimi ve sorumlu davranışları teşvik etmede kilit bir rol oynamaktadır. ${ }^{40}$ Özetle sağlıklı ilişkiler büyük ölçüde güvene dayanır. Bir bireyin güven yaratmak için hem karşıdakine güvenmesi hem de kendisine güvenilmesi gerekir. Günümüzde güven ilişkisinde asıl mesele, kişinin diğerinin davranışlarına ve sözlerine güvenebilmesi meselesidir.

Güvenin inşasında mahremiyete büyük bir pay biçilmektedir. Zira ikili veya çoklu ilişkilerde mahremiyetin sağlanamadığı durumlarda güvenin inşası da imkânsızlaşmaktadır. Güvenle yakından ilişkili olarak mahremiyet güvenin en önemli parçasıdır ve bireylerin belirli düzeyde kendilerine ait özel bir hayatlarının olmasını gerektirir. Mahremiyet cinsel yaşamda olduğu kadar sosyal ilişkiler ve arkadaşlıklarda da ihtiyaç duyulan bir şeydir. Mahremiyetin sağlanmasıyla güven ilişkisi de sağlamlaşmaktadır. ${ }^{41}$ Güven duygusunu sevginin bir bileşeni olarak görmemizde, özellikle sevginin anlam ve bileşenlerinde "güven" olgusunun dikkat çekici bir şekilde öne çıkması etkilidir. Güvenin olmadığı bir yerde aileyi söz konusu etmemiz anlamsız gözükecektir. Bir düzen temelinde inşa edilen evlilikte, eşlerin tutum ve davranışlarında birbirlerinin farklılıklarını kabul etmeleri ve özgürlüklerine müdahalelerinin sınırlı olması ancak güven duygusuyla aşılabilmektedir.

Sevgiyle yakından ilgili diğer manevi bileşenin "dinî inanç ve pratikler" olduğunu söyleyebiliriz. Zira yaptığımız niteliksel çalışmada, din olgusunun eşleri birbirine yakınlaştıran, evliliğin daha iyi gitmesi yönünde "pekiştirici" bir rol oynadığ 1 yönünde görüşler mevcuttur. Çalışmanın bulgularına göre dinî inanç ve pratikler bir evlilikte kimi zaman saydığımız diğer manevi bileşenlerin de üzerine geçebilmektedir. Hatta iki farklı görüş bildiren katılımcıların ifadelerinde dinî inancı algılama ve deneyimleme, ailevi ilişkiler açısından farklı anlayışlara işaret etmektedir. "Dinî inancı yoksa boşanırım" diyenlerin eğilimleri radikal ve sert bir tutum içerisindeyken "Dinî inancı yoksa sabırla dinî inancı benimsemesini beklerim" diyenlerin ise daha toleranslı ve yumuşak bir yaklaşım içerisinde oldukları görülmüştür. Eşler, birbirlerine olan yaklaşım ve tutumlarında genellikle dinî ayet ve hadislere referansla hareket edebilmektedir. Katılımcılarla yapılan görüşmelerde evliliğin başlangıcından sürdürülmesine kadar aynı dinî inanca sahip olmanın yanı sıra

\footnotetext{
${ }^{37}$ Gül, Yeni Kentsel Aile, 126-127, 134-138.

${ }^{38}$ Harry T. Reis vd., "The Relationship Context of Human Behavior and Development", Psychological Bulletin 126/6 (2000).

${ }^{39}$ Caryl E. Rusbult vd., "Interdependence, Closeness, and Relationships", Handbook of Closeness and Intimacy, ed. D. J. Mashek A.P. Aron (Mahwah, NJ: Lawrence Erlbaum Associates, 2004).

${ }^{40}$ R. M. Kramer, "Trust and Distrust in Organizations: Emerging Perspectives, Enduring Questions", Annual Review of Psychology 50 (1999).

${ }^{41}$ Antohny Giddens, Modernite ve Bireysel Kimlik: Geç Modern Çağda Benlik ve Toplum, çev. Ümit Tatlıcan (İstanbul: Say Yayınları, 2014), 128-129.
} 
dua ve pratiklerin de eşleri birbirine yakınlaştırmada ve ilişkilerde yaşanan olası çatışmaları atlatabilmede önemli bir rol oynadığı görülmüştür. ${ }^{42}$ Ancak çalışmanın bulgularıyla ilgili ortaya çıkan dikkat çekici bir unsur da gözden kaçmamaktadır. Ailede eşlerden birinin evlilik esnasında yaşadığ inanç zayıflığı veya dinî pratiklerde yaşanan bazı eksikliklerine rağmen eşler, "evliliği sürdürme" noktasında çaba sarf etmektedirler. Bu durum, Türk toplumunun aileye verdiği özel bir önemle açıklanabilir.

\section{Sonuç}

Kentleşme sürecinin zorlu etkilerine maruz kalan ailenin, günümüzde de önemini ve varlığını koruyup korumadığı din sosyolojisi ve sosyoloji literatürünün önemle üzerinde durduğu meselelerden biridir. Nitekim bu değişim süreciyle birlikte aile, üyelerinin birbirine olan yabancılaşmasından, boşanmaya kadar zorlu bir sınavı vermiştir. Bu bağlamda aileyi mercek altına aldığımız çalışmamızdan elde ettiğimiz bulgularda; ailenin, geçirdiği birçok değişime rağmen önemini ve değerini koruması dikkat çekici olmuştur.

Çalışmamızda "sevginin eşler için anlamının" çok yönlü ve karmaşık bir doğası olduğu anlaşılmıştır. Kadınlar; sevgiye "fedakârlık, sadakat, değer ve saygı görmek, sorunlarının dinlenilmesi, paylaşılması ve anlaşılmak" gibi anlamlar yüklerken erkekler; "ilgi görmek, sıcak bir tebessüm, saygı duyulmak ve sorunları paylaşmak" gibi anlamlar tanımlamaktadır. Ayrıca erkekler için "nezaketli davranmak, eşe hâl ve hatır sormak" gibi ifadeler de bağlılığı güçlendiren sevgi anlayışı olarak ortaya çıkmaktadır. Aile içi ilişkilerde sevgi anlayışlarının cinsiyet bağlamında belirgin bir farklılığ farklılaştığını görmek mümkündür. Eşler arasında gerçekleşen sevgi davranışlarının başkalarının yanında sürmemesi veya daha sınırlı olması, kadınların çoğunlukla dile getirdiği hususlardan biri olmuştur. Nitekim kadınların ve erkeklerin sevgiyi gösterme biçimlerinde aileden gelen kültürel bir anlayışın etkisi açıç̧a görülmektedir. Bu da sevginin kültürel bir dokuya sahip olduğu konusunda öne sürülen birçok görüşü doğrular niteliktedir. Çalışmada kadınların, sevginin gösterim tarzına büyük bir önem verdikleri görülmüştür. Kadınların, sevgi edimini erkeklerin tutum ve davranışlarında görme beklentileri, özellikle kadının erkeğin ailesiyle yan yana geldiği ortamlarda daha fazla ön plana çıkmaktadır. Erkeklerin, başkalarının yanında tutum ve davranışlarıyla sevgilerini göstermesi kadınlarda sevildiğini hissettirmektedir. Böylelikle sevilme hissinin kazandırdığı iktidar ile kadın, aile içerisindeki sevgi mücadelelerinde eşinin akrabalarına karşı avantajlı duruma geçmektedir. Zira yakın akrabalar arasında erkeğin sevgisine sahip olma isteği, aile içerisinde bir gerilim ve mücadele alanı yaratarak kadınların güç arayışlarını tetiklemektedir. Bu durum sevgiyi paylaşma kadar paylaşmama duygusunun da sevginin doğasında içkin olduğuna işaret etmektedir. Anlaşılan o ki aile içi ilişkilerde sevginin bencil bir tarafı da bulunmaktadır. Günümüz kent yaşamında sadece modern aile veya geleneksel alg1 ve yaşayışı sürdüren aile biçiminin değil senkretik aile türlerinin de ortaya çıtığı farklı bir yapılanma söz konusudur. Dolayısıyla erkeğin sevgisine sahip olma isteğinin gelin ve görümce/kayınvalide arasında yarattığ gerilimi, geleneksel ailede olduğu gibi değişmekte olan kent ailesinde de görmek şaşırtıcı değildir. Nitekim günümüzde de kent içerisindeki mesafelerin yakınlığına veya uzaklığına bakılmaksızın geleneksel ailedeki gibi ilişkilerini sıcak ve yakın tutan ailelerin varlığı gözden kaçmamaktadır. Hatta yaşanan ekonomik kayıplar/kaygılar veya başka sebepler ile aile büyükleriyle yakın ilişkiler kurmak ve onlardan destek almak neredeyse bir ihtiyaç haline gelmiştir. Her ne kadar yaşanan değişimlerin etkilerine karşı aileler kırılgan bir yapı gösterse de yine de kendi içlerinde güçlü manevi dinamikleri

42 Gül, Yeni Kentsel Aile, 143-154. 
barındırmaktadırlar. Bu anlamda Türk ailesinin evliliğe verdiği önem dikkat çekicidir. Kentleşmenin getirdiği zorluklara rağmen aile büyükleri, evli çocuklarından maddi ve manevi olarak kendilerini tamamen soyutlamamaktadırlar. Hatta kimi zaman aile büyüklerinin evliliklere aşırı müdahaleleri dahi söz konusu olabilmektedir. Öyle ki günümüzde aile büyüklerinin evliliklere müdahalelerinin boşanma nedenleri arasında sayılması, evlilikler üzerinde ailelerin etkisinin boyutunu göstermesi açısından önemli bir detaydır.

Çalışmamızda aile içi ilişkilerde sevginin yakından ilişkili olduğu birçok manevi unsurun öne çıktığını belirtmek gerekir. Saygı, fedakârlık, güven, sorumluluk, nezaket, şefkat ve din gibi manevi bileşenler, birbirleriyle ilişkili olduğu kadar sevgiyle de yakından ilişkili olarak öne çıkmaktadır. Sevgi ve söz konusu bu manevi bileşenler arasındaki güçlü etkileşimler, ailede eşler arasındaki bağları güçlendirmektedir. Fedakârlık, şefkat, dinî inançlar ve pratikler boyutunda kadınların, erkeklerle kıyaslandığında bu manevi değerlere büyük önem atfettikleri ve bu değerleri aile içi tutum ve davranışlara uygulamada erkekler üzerinde yönlendirici bir etkiye sahip olduğu anlaşılmaktadır. Bu manevi unsurlardan özellikle fedakârlık, şefkat, dinî inanç ve pratikler neredeyse kadın kimliğiyle özdeşleşmekte ve bu unsurların cinsiyet karakterinin kadınsı bir yapı arz ettiğini ifade etmek mümkündür. Ayrıca evliliklerde, erkeklerin de en az kadınlar kadar fedakâr olduğu ancak erkek fedakârlığının genellikle kadınlar tarafından çok fazla dile getirilmediği anlaşılmaktadır.

Öte yandan çalışmada dinî inanç ve pratikler ile sevgi arasında çok fazla gündeme gelmeyen yakın bir etkileşimin olduğu görülmüştür. Hatta sevginin önemli bir bileşeni olarak dinî inanç ve pratikler; evliliğin kuruluşundan, eş seçimi ve evliliğin devamına kadar önemli bir unsur oluşturmaktadır. Kentleşmeyle birlikte gündelik yaşam pratiklerinde bir değişme olsa da dinî alanda maneviyatın güçlü olduğu ve dinin hâlen önemli bir unsur olarak kent ailesinde karşımıza çıktığı anlaşılmaktadır. Bilhassa kadınların dinî alana verdiği önem açısından, dinî inanç ve pratiklerin cinsiyet karakterinin kadınsı bir yapı arz ettiğini söyleyebiliriz. Bunun yanı sıra dinin de ailede diğer manevi bileşenlerle iç içe bulunduğu ve onları beslediği gözlenmiştir. Çalışmamızda dikkat çeken bir diğer unsur ise kadınların eş seçerken inançlı ve dindar bir erkeği tercih etmesidir. Erkeklerle kıyaslandığında kadınların, bu konuda daha hassas olduğu görülmektedir. Ancak önemli bir hususu belirtmek gerekir ki evliliğin kurulmasından sonraki aşamalarda, dinî inanç ve pratikler üzerinde yaşanan olası gerilimlerde aile olgusunun dine baskın geldiğini söylemek mümkündür. Zira günümüz kent ailesinde eşlerden birinin evlilik esnasında yaşadığı inanç zayıflığı veya dinî pratiklerde yaşanan bir eksiklik, eşlerin "evliliği sürdürme" gayretini engellememektedir. Bu durumun günümüz kent ailesinde öncelikli bir etken olarak öne çıtığı görülmektedir.

\section{Kaynakça}

Atak, Hasan - Taştan, Nuray. "Romantik İlişkiler ve Aşk". Psikiyatride Güncel Yaklaşımlar 4/4 (2012), 520-546.

Bahr, Howard M. - Bahr, Kathleen S. Toward More Family-Centered Family Sciences: Love, Sacrifece and Transcendence. New York: Lexington Books, 2009.

Bauman, Zygmunt. Akışkan Aşk. çev. Işık Ergüden. İstanbul: Versus Kitap, 2. Basım, 2012.

Burr, Wesley R. vd. Sacred Matters: Religion and Spirituality in Families. Newyork: Routledge, 2012.

Cole-King, Alys - Gilbert, Paul. "Compassionate Care: The Theory And The Reality". Journal Of Holistic Healthcare 8/3 (2011), 29-37.

Çağan, Kenan. "Ailenin İşlevleri”. Aile Sosyolojisi. ed. Kadir Canatan - Ergün Yıldırım. 83-93. İstanbul: Açılım Kitap, 2013.

Erdoğmuş, Zeki. “Türk Ailesini Postmodern Çağa Hazırlamada Sosyolojik Bir Bakış Açısı". Aile Kurultayı- Değişim Sürecinde Toplumsal Katılım ve Demokratik Değerler (16-18 Kasım 1994). Ankara 1995. 
Fromm, Erich. Sevme Sanatı. çev. Işıtan Gündüz. İstanbul: Say Yayınları, 1985.

Fromm, Erich. Sahip Olmak ya da Olmak. çev. Aydın Arıtan. İstanbul: Arıtan Yayınevi, 2003.

Giddens, Antohny. Modernite ve Bireysel Kimlik: Geç Modern Çă̆da Benlik ve Toplum. çev. Ümit Tatlıcan. İstanbul: Say Yayınları, 2. Basım, 2014.

Goleman, Daniel. Duygusal Zekâ. çev. Banu Seçkin Yüksel. İstanbul: Varlık Yayınları, 33. Basım, 2010.

Gottman, John - Silver, Nan. Evliliği Sürdürmenin Yedi İlkesi. çev. Ezgi Deniz. İstanbul: Varlık Yayınları, 2013.

Gökçe, Birsen. “Aile ve Aile Tipleri Üzerine Bir inceleme”. Hacettepe Sosyal ve Beşerî Bilimler Dergisi 8/12 (Mart-Ekim 1976), 46 - 67.

Gül, Hatice. Yeni Kentsel Ailenin Manevi Boyutları: Gaziantep Örneği. Kayseri: Erciyes Üniversitesi, Sosyal Bilimler Enstitüsü, Doktora Tezi, 2019.

Günerigök, Mustafa. Risk Toplumu ve Din: Yeni Bir Sosyolojiye Doğru. Ankara: Maarif Mektepleri, 2018.

Hökelekli, Hayati. "Şefkat". Dem Dergi. 3 (Ocak-Şubat-Mart 2008), 109-113. Erişim 1 Aralık 2020. https://media.dem.org.tr/dir/dem/dem/yayin/goruntuleme/20181207204305 0.pdf.

Kramer, R. M. "Trust and Distrust in Organizations: Emerging Perspectives, Enduring Questions". Annual Review of Psychology 50 (1999), 569-598.

Özgüven, İbrahim Ethem. Evlilik ve Aile Terapisi. Ankara: PDRM Yayınları, 2000.

Reis, Harry T. vd. "The Relationship Context of Human Behavior and Development". Psychological Bulletin 126/6 (2000), 844-872.

Robins, Kevin. Into The Image: Culture and Politics in The Field of Vision. London: Routledge, 1996.

Rusbult, Caryl E. vd. "Interdependence, Closeness, and Relationships". Handbook of Closeness and Intimacy. ed. D. J. Mashek - A.P. Aron. 137-161. Mahwah, NJ: Lawrence Erlbaum Associates, 2004.

Satir, Virginia. Insan Yaratmak: Aile Terapisinin Başyapıtı. çev. Selim Yeniçeri. İstanbul: Beyaz Yayınları, 3. Basim, 2018.

Sayın, Önal. Aile Sosyolojisi: Ailenin Toplumdaki Yeri. İzmir: Ege Üniversitesi Edebiyat Fakültesi Yayınları. No. 57. 1990.

Sorokin, Pitirim. "Özgeci Sevgi”. çev. Mehmet Harmancı. Aşkın Anatomisi. der. A. Krich. $229-242$. İstanbul: Say Yayınları, 2005.

Van Lange, Paul A. M. vd. "Willingness to sacrifice in close relationship". Journal of Personality and Social Psychology 72/6 (1997), 1373-1395. 